\title{
Analysis on Competitive Strategy of Hotel Enterprises in the Context of Industrial Transformation
}

\author{
A Case Study of Jinling Hotel*
}

\author{
Xinwei $\mathrm{Su}$ \\ College of International Business \\ Liming Vocational University \\ Quanzhou, China 362000 \\ Faculty of International Tourism and Management \\ City University of Macau \\ Taipa, China 999078
}

\author{
Yanxin Kang \\ College of International Business \\ Liming Vocational University \\ Quanzhou, China 362000
}

\begin{abstract}
Under the dual pressure of multiplicative downward pressure of current global economy and the transformation of domestic macro policies, the transformation and upgrading of the hotel industry will be an inevitable choice. Jinling Hotel is the first listed hotel enterprise in China. This paper teases out various scholars' researches that take the Jinling Hotel as an example. Based on the materials released on Jinling Hotel's official website and the financial data published by Shanghai Stock Exchange, this paper has discussed the strategy of Jinling Hotel by using SWOT, internal and external environmental analysis, network analysis, and trend analysis, and proposed strategic management tactics for Jinling Hotel.
\end{abstract}

Keywords-Jinling Hotel; strategic management; tactical management

\section{INTRODUCTION}

Enterprise strategy research is a process of in-depth analysis and has an essential reference value for the enterprise in its development process. By using the materials published on the network by Jinling Hotel and the financial data released by the Shanghai Stock Exchange as data source, this paper combines the relevant documents, makes an in-depth analysis, uses various analysis methods, strives to conduct a comprehensive and profound analysis on strategic management of the Jinling Hotel, so as to provide valuable references for other enterprise.

With shares of stock held by Nanjing Jinling Hotel Group Co., Ltd, Jinling Hotel Co., Ltd was established on December 2002 and listed on April 2007 on the Shanghai Stock Exchange, and this company became the first IPO in China's hotel industry after full circulation and the first listed tourism company in Jiangsu Province. At the end of 2016, there were

*Found Project: Research Project Research Project of Young Teachers in Education Department of Fujian Province (No. JA11386S); Research Project of Education and Teaching of Liming Vocational University (No. LJ201433); Research Project of Education Science of Fujian Province (No.FJCGGJ12030)
128 Jinling chain hotels in nineteen autonomous regions, provinces, cities in China, and the company's management scale ranked 37th among the "Global Top 50 Hotel Groups". The company maintained the first in the total number of fivestar hotels under the jurisdiction in the whole country, forming a national expansion layout with Eastern China as the leader. It has creatively achieved a success that Chinese people have constructed a world-class hotel, and realized a leap from single hotel to brand chain operation and cross-regional tourism development. In the past 34 years, it has always maintained a leading position in the Chinese hotel industry.

\section{RESEARCH STATUS}

Taking CNKI database as the data source and "Paper Title" as the search term, this paper has obtained 118 related documents, including 50 news reports and 68 academic papers. From the distribution graph of documents, see "Fig. 1", it can be seen that Shi Boming began to study Jinling Hotel as early as 1980, but his main focus is on the architecture of Jinling Hotel[1]. Yin Ying, who is the first person to study the strategy of Jinling Hotel, made the first report on Jinling Hotel's strategy in China Tourism News in 2004[2]. Based on the A\&K model, Wang Jianling has introduced a service quality indicator system and constructed a gray advantage analysis model of influence factor of brand extension. Taking Jinling Hotel as an example, she conducts an empirical analysis, and finds that the process quality is more important than result quality and the quality perception of parent brand is crucial in brand extension, which provides a good reference for the brand promotion of the Jinling Hotel [3]. It is a worthy concern that three masters have carried out a more profound strategic research on the Jinling Hotel. Ju Dan compares the Jinling Hotel with Jinjiang Group from the perspective of the enterprise's expansion model, and argues that making the group bigger is an effective means to play the scale economy and scope economy, as well as an effective model for enterprises to be competitive [4]. Zhang Yu studies the 
enterprise's competitiveness from the perspective of technological innovation, and proposes that the hotel industry is the forward position for the application of high and new technology and only by improving innovation in science and technology made hotel invincible [5]. Zhang Xiaomei adopts the Peak-End Rule to study the customer experience in Jinling Hotel and puts forward a series of suggestions for enterprise's management on customer experience [6].

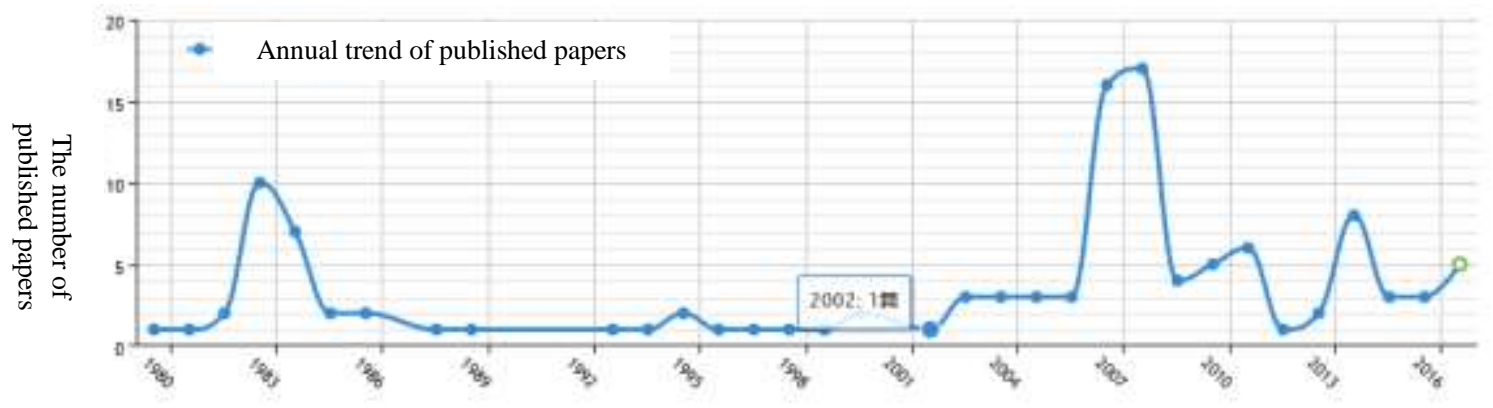

Fig. 1. General trend chart of documents distribution.

From the discipline distribution of scholars' research documents on Jinling Hotel, most are concentrated in the service economy (accounting for $30.46 \%$ ), building science (accounting for 13.71\%), investment (accounting for 12.18\%) and finance (accounting for $11.86 \%$ ), and there are only six articles on tourism, accounting for only $3.09 \%$. Therefore, it can be seen that Jinling Hotel is widely concerned, but there are few documents on strategic level see "Fig. 2".

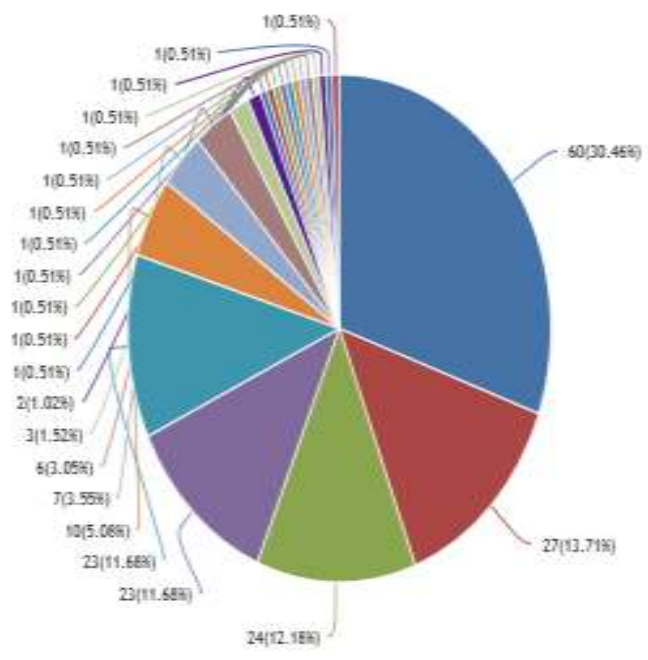

Service economy

Building science and engineering Investment

Finance

Security

Trade economy

Enterprise economy

Tourism

Industrial economy

Market research and information

Chinese literature

News and media

Electric power industry

Ideological and political education

Inorganic chemical industry

Computer hardware technology

Archaeology

Art calligraphy sculpture and photography

$1 / 2 \mathbf{V}$

Fig. 2. Discipline distribution of related documents on Jinling Hotel.

Taking the word of "hotel" and "strategic management" for retrieval, ducting the news reports, there are 91 related documents. This paper analyzes the keywords of all documents and finds that scholars' researches on hotel strategic management are mostly concentrated on "Strategic Cost Management", especially the strategic management of economy hotel, for example, master thesis of Study on
Strategic Management of China's Economy Hotels by $\mathrm{Yu}$ Shaobin [7]. The next is the value chain analysis in strategic cost management, such as Research on Strategic Hotel Cost Management of Economy Hotels Under the Perspective of Value Chain by Yin Qianqian, et al [8], and others are more evenly distributed see "Fig. 3". 


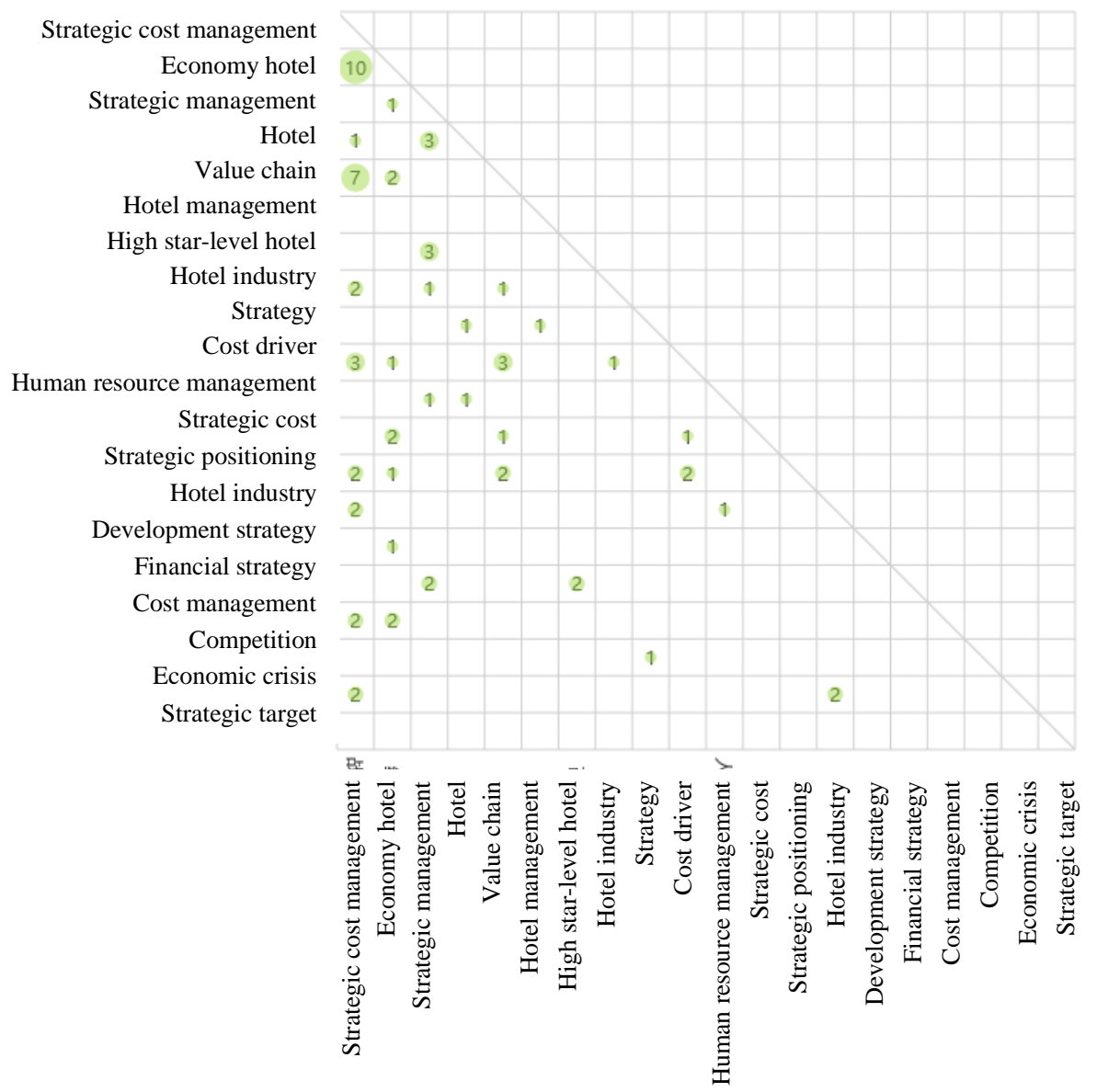

Fig. 3. Matrix graph of literature keywords co-occurrence.

\section{THE ANALYSIS OF THE EXTERNAL ENVIRONMENT OF THE ENTERPRISE}

\section{A. General Environmental Analysis}

2017 is an important year for the country to implement the "Thirteenth Five-year" Plan, and it is also a year of deepening supply-side structural reform. In economy, China seeks improvement in stability, and the growth quality has been steadily improved, moreover, supply-side reform will further promote consumption growth and consumption upgrades. The Party Central Committee and the State Council attach great importance to the development of tourism, and write the "Tourism +" into 2017 Central No. 1 document, "Healthy China 2030" Plan Outline issued by State Council regards tourism as a key field for the development of new and healthy form of industry and the "Thirteenth Five-year" Tourism Development Plan is released as key specialized planning of country, which shows that tourism has fully integrated into the national strategic system.

The tourism development conference of Jiangsu Province clearly puts forward that Jiangsu will be built into a leading tourism province in China and the tourism industry will be cultivated into an important strategic industry in the economy of Jiangsu. The conference also proposes to deepen the integration and innovation of tourism, strengthen the brand building of tourism enterprises, accelerate the establishment of the provincial tourism industry group, support the Jinling and other tourism companies to expand the scale, improve management and export brands, and build a new opening pattern for Jiangsu's tourism.

In the past two years, with the successful holding of largescale meetings including Youth Olympic Games and China Food \& Drinks Fair, the popularity of Nanjing in the country and even in the world has been further enhanced. The International Congress \& Convention Association (ICCA) publishes the ranking list of destination cities of the global conference. Nanjing ranks the fourth in China (inland), second only to Beijing, Shanghai and Hangzhou. Jinling Hotel is awarded the "2016 Best Conference Hotel in China" by China Meetings Industry Convention. Nanjing municipal government's "Opinion on the Implementation of Promoting Tourism Investment and Consumption" proposes to incorporate the propaganda and promotion of tourism into various official investment promotion activities, accelerate research and development of special products for the award tourism, introduce more international conferences and professional exhibitions to Nanjing, and build Nanjing into an international award conference city and the capital of domestic conventions and exhibitions. At present, there are nearly one hundred of the world's top 500 enterprises, and about 400 
large-scale transnational company's regional headquarters, functional institutions, and domestic top 500 companies have settled in Nanjing. During many years of business cooperation, Jinling Hotel has accumulated rich resources and has always maintained leading advantages in market.

In the next ten years, especially during "the thirteenth FiveYear Plan", it will be a significant period of strategic opportunity to cope with aging of population. China has accelerated the development of pension services and general office of the state council has issued Some Suggestions on Completely Liberating Pension Services Market to Improve the Quality of Pension Services. Jinling Holdings Ltd and Department of Finance of Jiangsu Province jointly initiate and establish "Jiangsu Province pension services investment funds", devote to create new pension services model in China, construct a pension services china integrating pension actual case construction, operating service management and industrial capital operating, which will actively promote the development and operation of "Jinling Tianquan lake tourism ecological park" project.

\section{B. Analysis of Industrial Structure}

With the dual promotion of consumption upgrade and supply-side structural reform of tourism, the scope of tourism accommodation is expanding and accommodation industry becomes more diversified, thus the so-called "accommodation jungle" is formed. However, from the perspective of accommodation standardization, the entire accommodation industry is forming a situation of tripartite confrontation of star hotels, brand hotels and non-standardized accommodation. In particular, homestay inn has developed vigorously in China, and the country and people pay more attention to this industry. After a relatively extensive development stage, it has gradually entered the standard management stage in the recent two years, and some provinces even the country have gradually issued some stipulations on homestay management. The scale of the homestay industry is expanding. According to the data of the third economic census and the data of the National Bureau of Statistics, it is concluded that the accommodation facilities above the scale of our country have about 8.8 million in 2016, about 6 million 350 thousand rooms and 580 billion yuan for the accommodation industry. At the same time, the brand and chain rate of the hotel industry are also increasing.

The Chinese economy will continue to face substantial downward pressure due to the influences of many factors including the lack of new growth support point, massive overcapacity, tepid private investment, capital's "transformation from the substantial economy from to fictitious economy", and increased financial risk in China. China's hotel industry has not yet shaken off the trend of striking the bottom, and most indicators in the hotel market are still in a downward trend, and domestic high-end hotels are struggling and still face greater pressure on the improvement of performance. The business promotion and improvement at the micro level can hardly change the current pattern and status of the hotel industry. The oversupply problem in hotel industry is more prominent. The proportion of international brands in high-end hotels is increasing, and more and more foreign-owned hotel groups have expanded to the Chinese market, which aggravates the competition in the industry market. In the past three years, Nanjing has increased more than 20 high-end hotels with the size of more than 4000 guests. It is expected that Nanjing will increase the five-star hotels to 50 in the next three to five years. The increasingly severe market competition and the continuous increase in labor costs, raw material costs and energy costs have posed great challenges to the company's hotel business operations. ${ }^{1}$

\section{THE ANALYSIS OF THE INTERNAL ENVIRONMENT OF THE ENTERPRISE}

\section{A. Top Design}

Facing complicated and severe operating environment, the Company strengthens the institutionalization and efficient construction of the board of directors, teases out and standardizes the governance structure of legal person of branch and subsidiary company, clarifies the management responsibilities of the board of directors and management level, establishes a multi-level target responsibility management system, and strengthens financial inspection and audit supervision for the important business and key positions. The Company also signs the responsibility agreement of operation target and safety goal with the branch and subsidiary company, strengthens business management and control, budget management and performance appraisal, and first issues the Internal Control Assessment Report in the Chinese tourism industry in eight consecutive years, further enhancing the governance mechanism and operational efficiency. The Company actively responds to the reform of country's tax policy of replacing business tax with value-added tax, standardizes the financial system, fund management and internal control process, fully guarantees the customer service under the new tax system, and realizes the reduction of tax burdens and improvement management.

The Company deepens the innovation of its operating mechanism and optimizes the ownership structure of its subsidiaries. It plans to complete the delisting and transfer of $55 \%$ equity of World Trade Center Co., Ltd, organizes and implements the change and reelection, articles of association revision and mechanism adjustment of New Jinling Hotel Co., Ltd, World Trade Center Co., Ltd and Huide Property Co., Ltd, studies the reform plan of mixed ownership of subordinate enterprises, and discusses investment cooperation with strategic investors, so as to create conditions for stimulating business vigor and protecting the rights of state-owned assets. It strengthens the interaction mechanism with investors, maintains efficient multi-path communication with more than 120 securities agencies, increases the publicity of hotel transformation and innovation and development of the pension industry, which improves Jinling's brand image and market value management in the capital market. The Company has won the first prize in the evaluation of "the Best Board of Directors of Chinese Listed Companies" and become the benchmark for the governance of listed companies in China. It has been evaluated as "Top 100 Most Core Competitive China's Listed Companies" and "Most Influential Enterprises

China Tourism Accommodation Industry Development Report 2017, China Tourism Academy 
among Industry Brand in China's Listed Companies" by the development and research institute of Chinese listed companies.

\section{B. Analysis of Business Performance}

In 2016, the Company had a business income of $834,650,900$ yuan, a year-on-year growth of $9.97 \%$. Among it, the total business income was 414,673,600 yuan and accounted for $49.68 \%$ of total revenue, a year-on-year growth of $0.69 \%$; the commodity trade income was $247,292,900$ yuan and accounted for $29.63 \%$ of total revenue, a year-on-year growth of $26.31 \%$; the property management income was $20,426,500$ yuan and accounted for $2.45 \%$ of total revenue, a year-on-year growth of $13.32 \%$; house rental income was 140,514,000 yuan and accounted for $16.84 \%$ of total revenue, a year-on-year growth of $14.29 \%$. The Company's full-year total profit reached $75,587,500$ yuan, a year-on-year growth of $19.74 \%$.
The net profit attributable to owners of the parent company was 41,628,200 yuan, a year-on-year decrease of $21.61 \%$. At the end of 2016, the Company's total asset was 3.059 billion yuan, a decrease of $7.63 \%$ from the end of the previous year; the net profit was 1.399 billion yuan, a decrease of $2.92 \%$ from the end of the previous year. In the light of the evaluation of the customer satisfaction index of the Jiangsu Provincial Quality Association, the customer satisfaction of Jinling Hotel is $99.17 \%$, and the customer loyalty is $96.50 \%$, and the corporate image index is 99.44 , and it always maintains the leading position in the industry. Only from the financial data of 2016 , it seems that we cannot see the performance changes of the Jinling Hotel. Therefore, this paper collates its eleven-year financial data from the financial report of Jinling Hotel in 2006-2016 see "Table I".

TABLE I. JinLING Hotel Business PERFormanCE LIST (2006-2016)

\begin{tabular}{|c|c|c|c|c|c|c|}
\hline \multicolumn{2}{|c|}{ 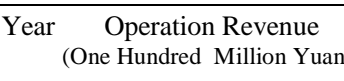 } & Growth Rate & \multicolumn{2}{|c|}{$\begin{array}{cc}\text { Total Profit } \\
\text { (Ten Thousand Yuan) }\end{array}$} & \multicolumn{2}{|c|}{$\begin{array}{l}\text { Net Asset } \quad \text { Growth Rate } \\
\text { (One Hundred Million Yuan) }\end{array}$} \\
\hline 2006 & 3.41 & $7.50 \%$ & 6390.5 & 16.42 & 3.75 & $8.38 \%$ \\
\hline 2007 & 4.09 & $19.84 \%$ & 8852.03 & $38.50 \%$ & 8.78 & $134.13 \%$ \\
\hline 2008 & 4.21 & $3.09 \%$ & 9276.44 & $4.79 \%$ & 9.14 & $4.03 \%$ \\
\hline 2009 & 4.42 & $4.81 \%$ & 11861.2 & $27.86 \%$ & 9.99 & $9.34 \%$ \\
\hline 2010 & 5.15 & $16.36 \%$ & $14,763.73$ & $24.47 \%$ & 11.11 & $11.26 \%$ \\
\hline 2011 & 7.00 & $36.13 \%$ & 17953.52 & $21.61 \%$ & 11.99 & $7.84 \%$ \\
\hline 2012 & 6.07 & $-13.38 \%$ & 15172.42 & $-15.49 \%$ & 13.09 & $9.19 \%$ \\
\hline 2013 & 5.35 & $-11.85 \%$ & 9154.24 & $-39.67 \%$ & 13.46 & $2.88 \%$ \\
\hline 2014 & 6.13 & $14.59 \%$ & 4939.1 & $-46.05 \%$ & 13.62 & $1.18 \%$ \\
\hline 2015 & 7.36 & $20.07 \%$ & 5551.79 & $12.40 \%$ & 14.00 & $2.78 \%$ \\
\hline 2016 & 8.35 & $9.97 \%$ & 7558.75 & $19.74 \%$ & 13.99 & $-2.92 \%$ \\
\hline
\end{tabular}

Since the listing of the Jinling Hotel, the growth rate of operating income has continued to increase. Except for negative growth in 2012 and 2013 affected by macroeconomic policies, the average growth rate has been more than double digits. What is noticeable is that the Company's business revenue has not started to grow until 2015, after the first negative growth in 2012, but the growth rate in 2016 has shrunk dramatically see in "Fig. 4". Overall, Jinling Hotel's operating income maintains a growth trend, but the growth rate is extremely unstable. a. Note: The above data are from the annual report of Jinling Hotel Co. Ltd

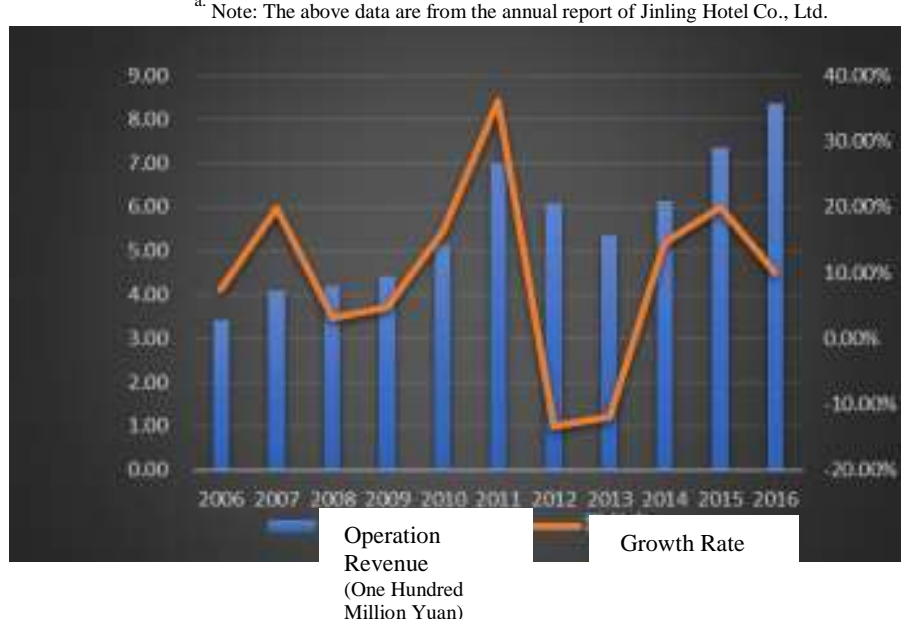

Fig. 4. Jinling Hotel's business revenue and growth rate (2006-2016).

From the perspective of net profit, the Company's revenue is not very satisfactory. Net income reached its peak value of $179,535,200$ yuan in 2011. Prior to 2012, the average growth 
rate of net profit remained above $20 \%$. The impact of macroeconomic policies in 2012 has become a watershed for the operation of the Jinling Hotel. From 2012 to 2014, net profit had a negative growth for three consecutive years, which were $15.46 \%, 39.67 \%$, and $46.05 \%$, respectively. Negative growth rates have continued to increase, and it started to grow again in 2015. Only from the numerical point of view, the Company's net profit did not surpass the 2006 profit value until 2016 see in "Fig. 5".

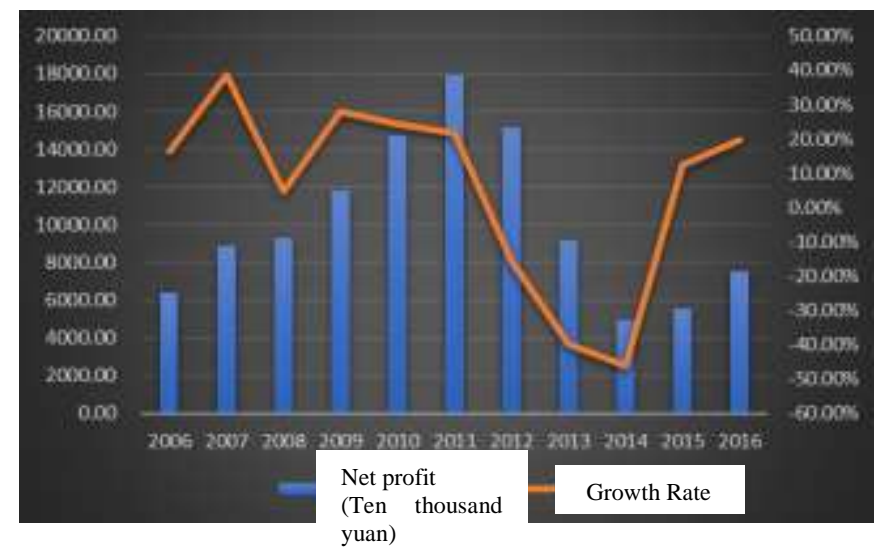

Fig. 5. Jinling Hotel's net profit and growth rate (2006-2016).

From the changes in the profit margin of the enterprise see in "Fig. 6", Jinling Hotel's profits began to decline from 2011, and operating income and net profit began to shrink in 2012. From this, it can be seen that as early as 2011, the realization of the profitability of the company has already prompted the company's business changes that may occur. After 2016, the company's profit margin has slightly rebounded. However, combined with the changes in the net assets of the enterprise, the Company's net assets showed a negative growth in 2016. It can be seen that part of the company's profits comes from the contribution of net assets.

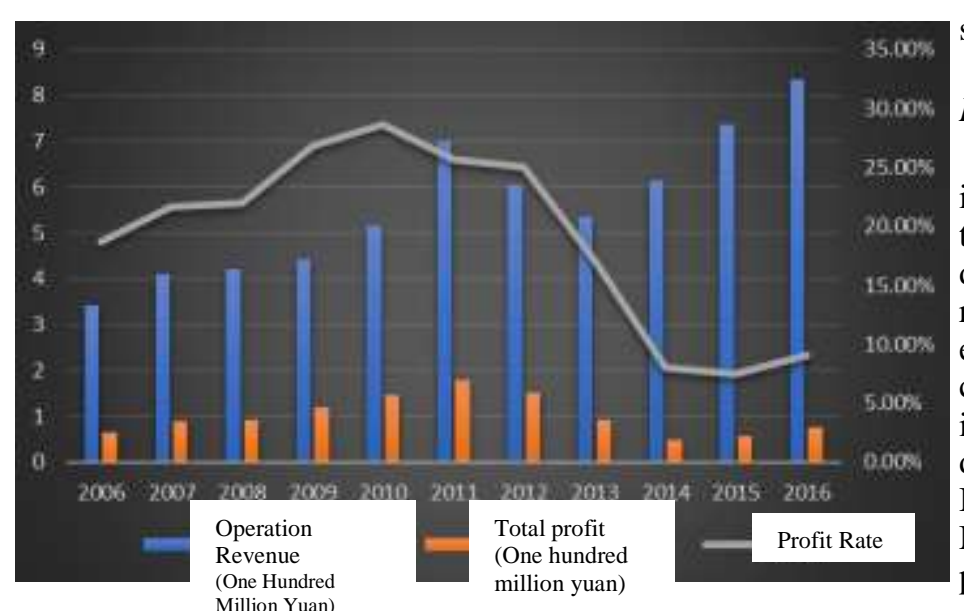

Fig. 6. Tendency chart of Jinling Hotel's income and profit margin.

From the net assets of the enterprise, after the listing of the Company in 2017, the assets expanded at a rate of $134.13 \%$, followed by a steady growth. However, there was a negative growth for the first time in 2016. From the perspective of the Company's operating income and net profit, the Company has a surplus, so it deserves further attention see in "Fig. 7".

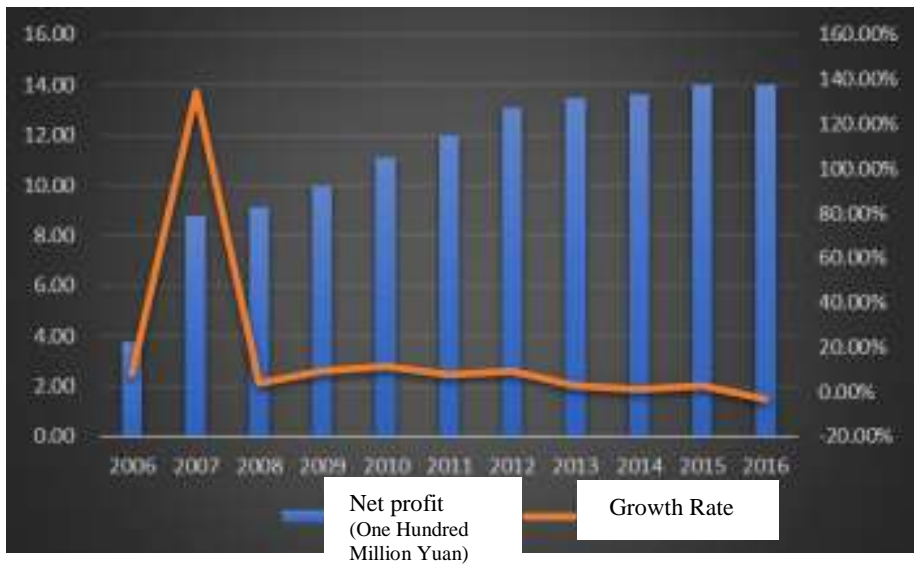

Fig. 7. Jinling Hotel's net assets and growth rate (2006-2016).

\section{Resource Analysis}

Jinling Hotel Co., Ltd was established on December 30, 2002 by Nanjing Jinling Hotel Group Co., Ltd, as the principal sponsor, which united Singapore Xinguang Investment Co., Ltd, Jiangsu Communications Holding Co., Ltd, Jiangsu Publishing Printing Materials Co., Ltd and Nanjing Fire Protection Technology Service Co., Ltd. It entered pre-listing tutoring period on December 31, 2002, and was officially listed on April 6, 2007. Jinling Hotel Group Co., Ltd was a provincial state-run enterprise established in October 2002 on the basis of the original Nanjing Jinling Hotel. In July 2005, "Jinling", as an excellent national brand, was included in the Implementation Outline for Accelerating the Development of Modern Service Industry during the period of "Eleventh FiveYear", and was given major support. As a controlling shareholder, Jinling Hotel Group Co., Ltd has inherent advantages in the policies. Its listing strategy is the right choice for Jinling Hotel Group because of seizing the opportunity, which provides an important source of capital for the subsequent financing expansion.

\section{Product Portfolio Analysis}

The Boston Matrix refers to that the enterprise, by studying its own products, carries out plan for the internal structure of the enterprise and conducts scheme for the products, distributes the limited resources of the enterprise into the reasonable product mix effectively, so as to ensure the enterprise income and obtain advantages in the fierce competition. The current main business of Jinling Hotel includes hotel service and management, tourism resources development, hotel material Trade and real estate development. Based on the two general indicators considered in the Boston Matrix, namely, market growth rate and market share, the product mix chart of Jinling Hotel is shown in "Fig. 8" below. 
Growth rate of market

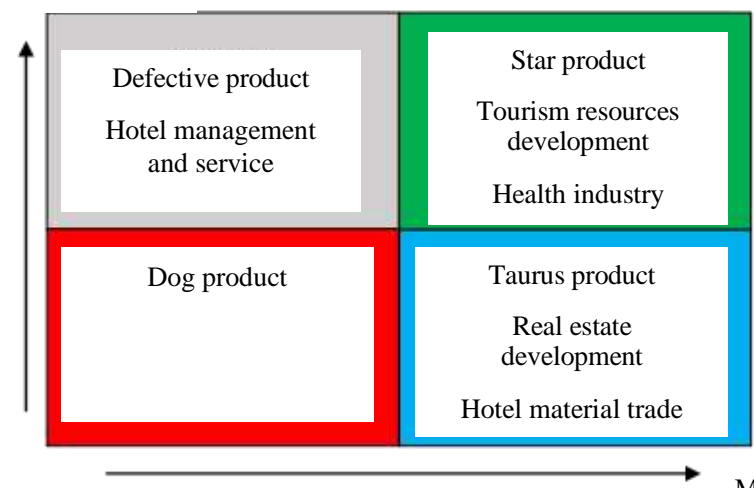

Market
share

Fig. 8. Boston Combination Chart of Jinlin Hotel Product Mix

As can be seen from the figure, Jinling Hotel has no dogs business, and business that fails or should be abandoned at present. In problem-type products, the enterprise has two businesses, namely, real estate development and hotel material trade, and the profits earned by these businesses are not high. Enterprises need to heavily invest to support their production and operation activities, and the funds that can be generated are very small. The enterprise needs to analyze further investment on "problem business", and determine the required investment amount to transfer it to the "star business", to analyze its future earnings and study whether it is worth investing. We should give up the business that is not worth investing. In the Taurus business, Jinling Hotel has businesses related hotel management. This type of business is in a mature, low-growth market with favorable market position, high profitability, and it does not need an investment. Instead, it can provide a lot of funds for enterprises to support the development of other businesses. Any business of the enterprise is developing towards this kind of business. In the star business, Jinling Hotel has tourism resources development and health industry. In the company's all businesses, the "star business" has an excellent long-term opportunity for growth and profit, but they are the main consumers of corporate resources and need a lot of investment. In order to protect and expand the leading role of "star business" in the growing market, enterprises generally should protect such businesses, and give priority to the resources they need in the short term to support their continued development.

\section{TREND PREDICTION ANALYSIS}

Hotel competition in the future is not merely the competition of geographical position, hotel brand, business area, service ability and products. Ultimately, it is the competition between people, and between the cognition of hotel owners and hotel general managers. The hotel owners and hotel general managers master the industry trend, market trend and consumers' changing trend, so as to create a successful hotel. In 2018, there are three major trends in the hotel industry that cannot be ignored.

The first is the smart trend of hotel. The hotel in the future will have a complete smart system, and realize informationization of hotel management and services through digitalization and networking. Based on meeting the guests' personalized needs and improving the quality, efficiency and satisfaction of hotel management and services, it will be a high-end design integrating information and communication technologies with hotel management. It is the management reform of the sharing and effective use of hotel resources and social resources. Therefore, it is the application innovation and integrated innovation of the processed information technology in hotel management.

The second is the hotel alternation trend. The inevitable trends in hotel alternation are personalization, thematicization, multi-functionalization, and humanity. The hotel is no longer a simple carrier for food, shelter, entertainment, etc, and will exert more unprecedented derivative functions.

The third is the trend of hotel crossover cooperation. Currently, Baidu, Tencent and Alibaba have entered the hotel industry. The entry of internet giants will drive the transformation of the traditional hotel industry. Next, luxury brands have gradually set foot in the hotel industry, such as Versace's ignoring its proper occupation to open the first hotel, and world's first Armani Hotel's appearance in Burj Khalifa Tower, Tonino Lamborghini uses its brand and Zhongyin Group takes advantage of the real estate industry and financial strength to jointly build a high-end hotel brand.

\section{CONCLUSION}

- Promote the equity reform of wholly-owned and controlled subsidiaries, optimize the ownership structure and governance mechanism, clarify the rights and obligation of management layers, stimulate operational vigor, and maintain the stability of business backbone teams.

- Deepen standardized management and improve dynamic management and control. Strengthen the management of financial budgets and internal audits, dynamic management and control of the management target responsibility system and human resources management and performance evaluation in the branch and subsidiary companies, and form a multi-level management responsibility management system, especially the enhancement of monitoring and supervision of key posts and key business links, so as to ensure the overall realization of the joint-stock company's business objectives.

- In the process of investment projects' planning, positioning and construction, we should make adequate research and demonstration, actively study relevant policies and regulations, and communicate effectively with the local government and the departments of land, urban construction, planning, real estate, National Development and Reform Commission and so on. In terms of the project of "Jinling Tianquan Lake Tourism Ecological Park", we will strengthen market survey, optimize the planning and construction plan design, enhance the construction organization and management, so as to build the readily marketable boutique properties for holiday and leisure and elderly care and health care. In the 
implementation process, the investment rhythm, scale, and construction progress are strictly controlled to effectively prevent and control investment risks.

- Continuously improve the refined management and standardization service system, build a green lowcarbon model, take some measures including ecological catering, green floors, energy-saving technological transformation, potential power tapping and consumption reduction, enhance research on building equipment management, environmental protection and energy conservation, and strengthen assessment and control on energy costs, to achieve the green ecological, efficient and energy-saving operation target.

- Actively expand property management projects, promote high-end building's property management and operation services, build the advantages of "Jinling property" brand, and open up new business growth space.

- $\quad$ Promote the professional operation of B2B and B2C in "Financial Centralized Purchasing Network". Optimize the organizational structure, innovate the operating model, exploit internal and external market space, enrich the resources of procurement suppliers, increase trading volume and activity, and expand Jinling brand's influence in the field of hotel-related derivatives.

- Improve the hierarchical development and management system of human resources, establish and implement the talent training and double-flow scheme for Jinling Hotel Branch, the headquarters of management company and the member hotels, implement the system of training in rotation for different levels, establish a talent team at all levels, and create multi-channel career development space, to adapt to the talent needs of the strategic transformation and upgrading of the enterprise.

- Implement Jinling talents development plan, give full play to the functional roles of the joint-stock company's talent development center, hotel branch, and the training platform of management corporation, build a talent training system for the entire joint-stock company and the group hotel sector, implement the combination of internal training and external introduction, optimize the structure of the talent team, advance the career development plan, and create conditions for the reserve, use, flow, and training of talents.

- Perfect the mechanisms of talent training, introduction, selection, promotion, flow, deployment, assessment and evaluation, improve the compensation management system and reward and punishment incentive mechanism, promote and inherit the Jinling culture that can enhance cohesion and stimulate creativity, and create a harmonious, efficient, and vigorous humanistic environment.
- The Company will strictly abide by national policies, laws and administrative regulations. In case that changes in national policies, laws, and administrative regulations affect the company's operating environment, the Company will adapt to changes in time and take targeted and effective measures to actively digest or avoid its impact.

\section{REFERENCES}

[1] Shi Boming. High Speed Construction of Jinling Hotel[J]. Architecture Technology. 1981(06): 30. 施伯鸣. 金陵饭店高速施工[J]. 建筑技术. 1981(06): 30

[2] Yin Ying. The Chain Operation of Jinling Hotel[N].China Tourism News, (3). 殷颖. 金陵饭店阔步走上连锁之路[N]. 中国旅游报, (3).

[3] Wang Jianling, Liu Sifeng, Wu Zuomin. Consumer's Evaluation of Hotel Brand Extension Based on Gray Prefereence Analysis[J]. Management Review. 2008(02): 28-32. 王建玲, 刘思峰, 吴作民. 饭 店品牌延伸影响要素的灰色优势评估——金陵饭店实证分析 [J]. 管 理评论. 2008(02): 28-32.

[4] Ju Dan A Comparative Study of Typical Expansion Models of Chinese Hotel Groups[D]. Chongqing Normal University, 2009. 鞠丹. 中国饭店 集团典型扩张模式的比较研究[D]. 重庆师范大学, 2009.

[5] Zhang Yu. Research on Hotel Enterprises' Competitiveness Based on Technological Innovation[D]. Nanjing University Of Finance \& Economics, 2015. 张宇. 基于技术创新的饭店企业竞争力研究[D]. 南 京财经大学, 2015.

[6] Zhang Xiaomei. Research on Customer Hotel Experience Based on Peak-End Rule[D].Dongbei University of Finance and Economics, 2013. 张晓梅. 基于峰终定律的饭店顾客体验研究[D]. 东北财经大学, 2013

[7] Yu Shaobin. Study on Strategic Management of China's Economy Hotels[D].University of International Business and Economics, 2004. 余绍涁. 中国经济型酒店战略管理问题研究[D]. 对外经济贸易大学, 2004.

[8] Yin Qianqian, Li Wuwu. Research on Strategic Hotel Cost Management of Economy Hotels Under the Perspective of Value Chain[J]. Commercial Times. 2010(08): 87-88. 印倩倩, 李武武. 价值链视角下 经济型酒店战略成本管理研究[J]. 商业时代. 2010(08): 87-88

[9] China Tourism Academy, China Tourism Accommodation Industry Development Report 2017[R], Tourism Education Press. 中国旅游研究 院, 中国旅游住宿业发展报告 2017[R], 旅游教育出版社

[10] China Tourism Academy, China Tourism Accommodation Industry Development Report 2016[R], Tourism Education Press. 中国旅游研究 院, 中国旅游住宿业发展报告 2016[R], 旅游教育出版社

[11] China Tourism Academy, China Tourism Accommodation Industry Development Report 2015[R], Tourism Education Press. 中国旅游研究 院, 中国旅游住宿业发展报告 $2015[\mathrm{R}]$, 旅游教育出版社 